\title{
Green-fingered gang could hold climate key
}

\section{David Adam, London}

Legions of devoted British gardeners may soon be enlisted into climate-change research, as part of an investigation of how weather patterns make their gardens grow.

The UK Climate Impacts Programme (UKCIP), a government-funded organization at Oxford University, is considering asking gardeners to report on the trees, shrubs and flowers in their backyards. The data could help researchers to identify long-term trends in plant development and growth, and then to match them with climate patterns.

The idea reflects rising interest in Britain in phenology - the study of seasonal plant and animal activity. Phenologists use observational data such as the first sightings of migratory birds in spring and first leaf-fall in autumn to identify changes in the biosphere. For example, the average dates of leaf unfolding and colouring have shown that the growing season in Europe is extending (see Nature 397, 659; 1999).

UKCIP officer Megan Gawith says that most research on climate change focuses on the possible effects on commercial agriculture and horticulture. "There has been no research on the domestic garden or heritage garden sector," she says. Together with organizations such as the National Trust and the Royal Horticultural Society, the UKCIP aims to investigate how climate change affects typical features of British gardens.

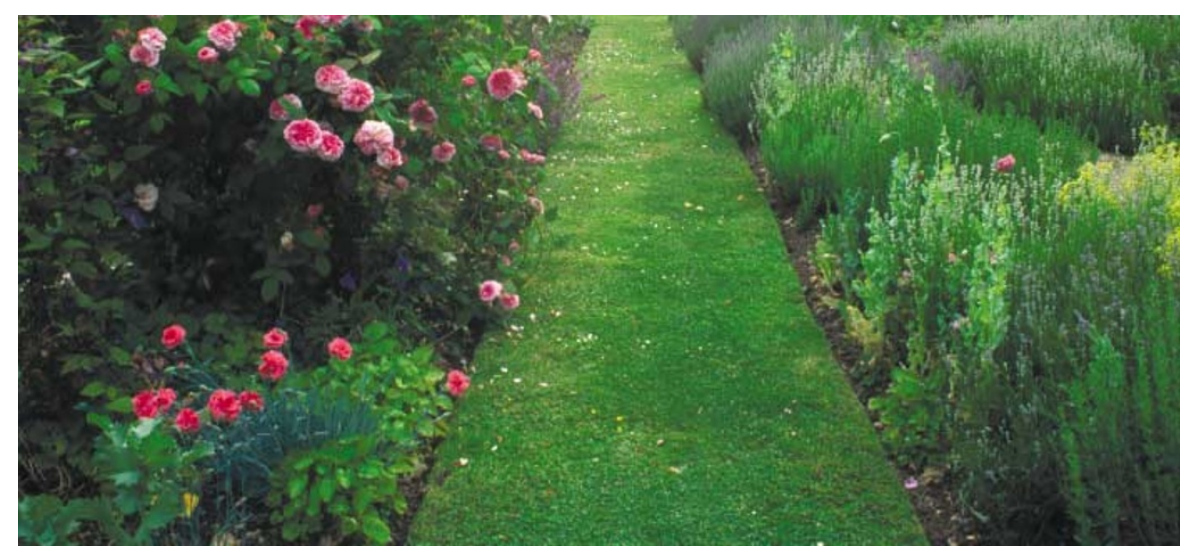

Research in bloom: there is growing interest in using domestic gardens to study climate change.

Data from domestic gardens may be "very valuable", says Frank Chmielewski, a crop scientist at the Humboldt University of Berlin and coordinator of the International Phenological Gardens, a pan-European network of 62 gardens containing genetically identical trees and shrubs. But he warns that it will take about 10 years to generate data to investigate climate change, and that many observations will be needed, as gardens are rarely typical of the surrounding environment.

"It would be better to advise gardeners to make phenological observations over a larger area," Chmielewski says, "not only in their own garden but also in the gardens of their neighbours." Observers should ignore flow- ers, he says, because they are more influenced by local conditions than are trees and shrubs.

Britain has around 27 million selfconfessed gardeners and a national obsession with the weather, making it ideal for such a study. Yet Mark Schwartz, a phenology researcher at the University of Wisconsin, Milwaukee, cautions that participants will need to be vigilant. "For the data to be useful, the observed events have to be defined quite sharply," he warns.

Gawith says the new scheme will probably be associated with an already established one, such as the UK Phenology Network, which already has 3,000 volunteer observers.

www.phenology.org.uk

\section{Earliest malaria DNA found in Roman baby graveyard}

\section{Alison Abbott}

Malaria experts are helping archaeologists to work out what caused the deaths of 47 babies whose bodies have been unearthed together in a fifth-century cemetery outside Rome.

The experts think the tiny skeletons including the bones of 22 miscarried fetuses - may have been victims of Plasmodium falciparum, an extremely virulent form of the organism that causes malaria. The Roman site could mark the northern edge of $P$. falciparum's penetration into Europe.

The archaeologists who excavated the site, led by David Soren of the University of Arizona in Tuscon, are intrigued by its unusual configuration. The cemetery, at Lugnano, Umbria, was created in a ruined villa. The bones were found at different depths, with more at higher levels.

"This is not the normal burial pattern for a Roman cemetery," says Soren. There were also signs of witchcraft at the burial site, including puppy skeletons, perhaps meant to ward off demons thought to cause disease. Study of the soil between the remains indicates that all the babies were buried within a few weeks.

Medics suggest a malaria epidemic as the cause of the deaths. The honeycomb pattern of many of the bones suggests anaemia, a symptom of malaria, and severe malaria is implied in the era's literature.

"Malaria is the most logical explanation for the deaths," says Mario Coluzzi, a parasitologist at the University of Rome.

DNA studies, due to be published next month in Ancient Biomolecules, show the presence of $P$. falciparum DNA in the bones of the oldest infant - the earliest malaria DNA ever identified.

"This is by no means proof that the cause of the infants' death was malaria," says Robert Sallares of the University of Manchester Institute of Science and Technology, UK, who led the DNA study, "but it allows it to remain a contender." http://www.coh.arizona.edu/lugnano

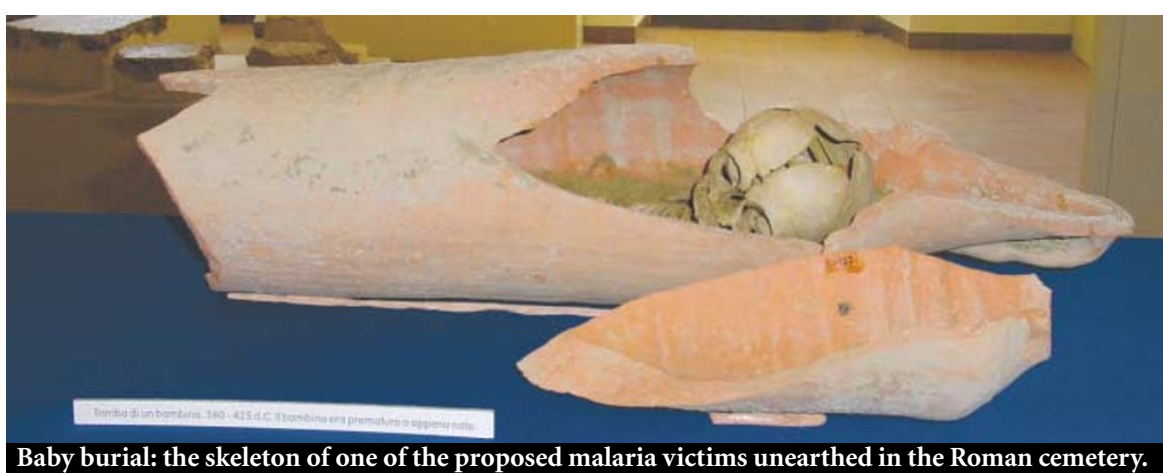

